\title{
The mystery of COVID-19 reinfections: A global systematic
}

3 Rubaid Azhar Dhillon ${ }^{19}$, Mohammad Aadil Qamar ${ }^{29}$, Omar $\operatorname{Irfan}^{3^{*}}$, Jaleed Ahmed Gilani ${ }^{4}$, Usama

4 Waqar $^{5}$, Mir Ibrahim Sajid $^{5}$, Syed Faisal Mahmood ${ }^{6}$

$5{ }^{1}$ Medical College, Riphah International University, Rawalpindi, Pakistan.

$6 \quad$ 2Ziauddin Medical College, Karachi, Pakistan.

$7 \quad{ }^{3}$ Centre for Global Child Health, Hospital for Sick Children, Toronto, Canada.

$8{ }^{4}$ Aga Khan University Hospital, Karachi, Pakistan.

$9{ }^{5}$ Medical College, Aga Khan University, Karachi, Pakistan.

$10{ }^{6}$ Section of Infectious Diseases, Aga Khan University, Karachi, Pakistan.

11 "These authors contributed equally to this work. RAD and MAQ are Joint first authors.

13 Abstract

\section{Background}

As the COVID-19 pandemic rages on, reports on disparities in vaccine roll out alongside

17 waves and variants of COVID-19, we conducted a systematic review to assess the determinants and disease spectrum of COVID-19 reinfection. 
medRxiv preprint doi: https://doi.org/10.1101/2021.07.22.21260972; this version posted July 25, 2021. The copyright holder for this preprint (which was not certified by peer review) is the author/funder, who has granted medRxiv a license to display the preprint in perpetuity.

All rights reserved. No reuse allowed without permission.

\section{Methods}

A comprehensive search covering relevant databases was conducted for observational studies reporting Polymerase Chain Reaction (PCR) confirmed infection and reinfection cases. Quality

22 assessment tool developed by the National Institute of Health (NIH) for assessment of case series was used. Meta-analyses were performed using RevMan 5.3 for pooled proportions of findings in first infection and reinfection with 95\% confidence interval ( $\mathrm{Cl})$.

25

37 quality.
Eighty-one studies reporting 577 cases were included from 22 countries. The mean age of patients was $46.2 \pm 18.9$ years with males accounting for $45.8 \%$ of the study population while $179(31.0 \%)$ cases of comorbidities were reported. The average time duration between first infection and reinfection was $63.6 \pm 48.9$ days. During first infection and reinfection, fever was the most common symptom ( $41.4 \%$ and $36.4 \%$, respectively) whilst anti-viral therapy was the most common treatment regimen administered (44.5\% and $43.0 \%$, respectively). Overall, comparable odds of symptomatic presentation and management were reported in the two infections. However, a higher Intensive Care Unit (ICU) admission rate was observed in reinfection compared to first infection (10 vs 3). Ten deaths were reported with 565 patients fully recovering. Respiratory failure was the most common cause of death (7/10 deaths). Seventy-two studies were determined to be of good quality whilst nine studies were of fair 
medRxiv preprint doi: https://doi.org/10.1101/2021.07.22.21260972; this version posted July 25, 2021. The copyright holder for this preprint (which was not certified by peer review) is the author/funder, who has granted medRxiv a license to display the preprint in perpetuity.

All rights reserved. No reuse allowed without permission.

39 As the first global-scale systematic review of its kind, our findings support immunization

40 practices given increased ICU admissions and mortality in reinfections. Our cohort serves as a

41 guide for clinicians and authorities for devising an optimal strategy for controlling the

42 pandemic.

43 Keywords: COVID-19, Reinfection, LMIC, HIC, Reactivation

44

45

46

47

48

49

50

51

52

53 
medRxiv preprint doi: https://doi.org/10.1101/2021.07.22.21260972; this version posted July 25, 2021. The copyright holder for this preprint (which was not certified by peer review) is the author/funder, who has granted medRxiv a license to display the preprint in perpetuity.

\section{Introduction}

55 The coronavirus, through its rapid spread and emerging variants, started in Wuhan amid

56 December 2019. It was declared a global pandemic in March 2020 and persists as a public

57 healthcare emergency. Over this period of more than a year, till date, the virus has infected more than 165 million individuals globally, and has resulted in more than 3.4 million deaths [1].

Currently, there are seven types of corona viruses known to infect humans: 4 are seasonal and cause limited upper respiratory tract infections, but 3 of them, namely SARS coronavirus (SARSCoV-1), Middle East respiratory syndrome (MERS), and SARS-CoV-2 cause severe disease [2]. SARS COV-2, the cause of the current pandemic, causes infection by binding to the angiotensin converting enzyme 2 receptor using a receptor binding domain in its spike protein for cell entry and ultimately, resulting in a respiratory syndrome [2-4]. The currently available vaccines target the spike protein[2]. However, mutations in the spike protein have been implicated in the reduction of small, but significant, efficacy of vaccines $[5,6]$ highlighting the scale of the

67 challenge COVID-19 places to the world. forward for a healthy, more "COVID-free" time, the concern of reinfection, recurrence, and mutant variants looms. The Center for Disease Control and Prevention (CDC), in their $27^{\text {th }}$

71 October 2020 update[7] raised concerns over reactivation of the disease and requested the

72 public to maintain infection control measures, such as wearing a mask in public, maintaining a six feet distance, regular hand washing, and avoiding crowded spaces. 
medRxiv preprint doi: https://doi.org/10.1101/2021.07.22.21260972; this version posted July 25, 2021. The copyright holder for this preprint (which was not certified by peer review) is the author/funder, who has granted medRxiv a license to display the preprint in perpetuity.

All rights reserved. No reuse allowed without permission.

74

75

76

77

78

79

80

81

82

Since Tillett et al.,[8] described the first confirmed case of COVID-19 reinfection from the USA, many authors have described their patient experiences of viral recurrence. The reason for this recurrence and its potential public health implication is a question that warrants explanation. Iwasaki et al.,[9] reason that perhaps a scant antibody response following the first infection could be the cause of a relapse. They emphasize on ascertaining a degree of specificity of the antibody (anti-nucleocapsid vs anti-spike antibody) at the time of reinfection, as well as determine the immune correlations of protection.

The public concern of whether vaccines could be a potential cure for the viral outbreak remains to be explained, with the obvious apprehension of whether a separate vaccine would be required for every variant of the virus. Till date, they have been four variants with significant mutations in the spike protein that have gained wide spread surveillance: B.1.1.7 (VOC 202012/01 or 20B/501Y.V1) which originated in the UK, B.1.351 (20H/501Y.V2) which originated from the Republic of South Africa, and P.1 (B.1.1.28.1) which was reported in travelers coming from Brazil [10]. A fourth double mutant variant of concern, labeled B.1.617 coming out from India, has been reported in March 2021 and is being investigated, considered to be a cause of the massive rise in infections in India currently experiencing its second wave [11].

A few questions remain though. Firstly, would immunity conferred by the first infection protect individuals from a serious disease process in the reinfection phase? And secondly, does reinfection imply that individuals who are already vaccinated experience a more severe COVID-
19 infection? The objective of this review, in addition to providing a comprehensive evidence 
medRxiv preprint doi: https://doi.org/10.1101/2021.07.22.21260972; this version posted July 25, 2021. The copyright holder for this preprint (which was not certified by peer review) is the author/funder, who has granted medRxiv a license to display the preprint in perpetuity.

All rights reserved. No reuse allowed without permission.

on COVID-19 reinfections including both pediatric and adult cases, is a unique comparison of

first infection and the reinfection disease spectrum, management, and outcomes.

\section{Methods}

98 The protocol of the review is registered with PROSPERO CRD42021239816. The review is

99 reported in accordance with the Preferred Reporting Items for Systematic Reviews and Meta-

100 Analyses (PRISMA).

\section{Search methods}

102 An exhaustive literature review was conducted on major databases: PubMed, WHO COVID-19

103 Database, Embase, China National Knowledge Infrastructure (CNKI) Database, Google Scholar,

104 manual searches of leading medical journals, and a pre-print server, medRxiv, covering the

105 timeline of January $1^{\text {st }}, 2020$, to March $16^{\text {th }}, 2021$. The following keywords were used to

106 conduct the search: COVID-19 and derivatives, reinfection, relapse, reactivation, as shown in S1

107 Table. Complementary searches were conducted in the John Hopkins Health Resource, Chinese

108 and US CDC Library. No language restrictions were applied. Key reference lists were additionally

109 screened for more studies.

\section{Selection strategy}

111 Observational studies (cohorts, case series, and case reports) reporting laboratory-confirmed

112 COVID-19 (RT-PCR) first infection and reinfection were considered for inclusion. Review articles,

113 commentaries, and letters not presenting any original data were excluded. Covidence software 
medRxiv preprint doi: https://doi.org/10.1101/2021.07.22.21260972; this version posted July 25, 2021. The copyright holder for this preprint (which was not certified by peer review) is the author/funder, who has granted medRxiv a license to display the preprint in perpetuity.

All rights reserved. No reuse allowed without permission.

114 (2016 edition) was used for screening by two reviewers independently and in duplicate. Any

115 discrepancies in selection were resolved by a third independent author.

\section{Data extraction and analysis}

117 The shortlisted articles were then extracted independently and in duplicate, on a structured

118 data form by two reviewers. The information extracted was as follows: Author names, date of

119 publication, country, setting of study, type of study, number of patients and age group, patient

120 information (age, gender and comorbidities), clinical evaluation (presenting symptoms in both

121 infections, travel/exposure history and infected family members), diagnostic tests

122 (nasopharyngeal swabs, antibody tests and timelines for initial infection and reinfection),

123 radiographic findings, therapeutic regimen (medications, isolation, and plasma therapy),

124 outcomes for both infections (hospitalization, ICU admission, complications, discharge, and

125 death) and antibody status after both infections. Disaggregated data by age groups (children

126 and adults) was extracted where available.

127 Categorical data was summarized as counts and proportions. The pooled proportions of

128 reported findings were calculated using Review Manager 5.3's random-effects model. $I^{2}$ was

129 calculated to examine statistical heterogeneity. The clinical features and outcomes were

130 compared accordingly between first infection and reinfection using pooled proportions and

131 their $95 \% \mathrm{Cls}$, supplemented by an odds ratio (OR).

\section{Quality assessment}

133 Quality assessment of included studies was conducted using the tool developed by the National

134 Institute of Health (NIH) for assessment of case series. Two authors independently scored the 
medRxiv preprint doi: https://doi.org/10.1101/2021.07.22.21260972; this version posted July 25, 2021. The copyright holder for this preprint (which was not certified by peer review) is the author/funder, who has granted medRxiv a license to display the preprint in perpetuity.

All rights reserved. No reuse allowed without permission.

135

136

137

138

139

140

141

142

143

144

145

146

147

148

149

150

151

152

153

154

155

quality of case series out of 8 , based on the clarity of study objectives, case definition, consecutive subject recruitment, comparability of subjects, definition and measurement of outcomes, length of follow-up, statistical methods, and results. A case series scoring 6-8 was considered good quality, 4-5 was considered fair quality and $<4$ was considered poor quality.

Consecutive subject recruitment, comparability of subjects and statistical methods were excluded from the scoring criteria for case reports, which were scored out of 5 . Case reports scoring 5 were considered good quality, scoring 3-4 were considered fair quality, and scoring $<3$ were considered poor quality.

\section{Results}

The comprehensive literature search yielded a total of 980 studies after removal of duplicates. After title and abstract screening, 87 studies were found to be eligible for a full-text assessment, of which, 81 were found to be eligible according to our inclusion criteria[8, 12-91]. The characteristics of the 81 included studies is shown in S2 Table. Six studies were excluded as they presented overlapping or missing data. An overview of the detailed systematic study selection process is presented in the PRISMA flow diagram (Fig 1).

\section{Fig 1. PRISMA Flow diagram of study selection process.}

Through consultation with a professional librarian, a search was conducted in leading medical journals and through duplication and screening processes, studies were selected.

In terms of study types, 45 studies (55.6\%) were case reports, and 36 studies $(44.4 \%)$ were case series. Studies were reported from 22 countries. Forty-eight out of 81 studies were reported from low-and-middle-income countries (LMICS). More than one-third of the studies were 
medRxiv preprint doi: https://doi.org/10.1101/2021.07.22.21260972; this version posted July 25, 2021. The copyright holder for this preprint (which was not certified by peer review) is the author/funder, who has granted medRxiv a license to display the preprint in perpetuity.

All rights reserved. No reuse allowed without permission. origin included in the review.

\begin{tabular}{|c|c|c|}
\hline Country & Number of studies & Number of reinfection cases \\
\hline Belgium & 2 & 2 \\
\hline Brazil & 7 & 45 \\
\hline China & 28 & 423 \\
\hline Colombia & 1 & 1 \\
\hline Ecuador & 1 & 1 \\
\hline France & 5 & 19 \\
\hline Hong Kong & 3 & 3 \\
\hline India & 4 & 8 \\
\hline Iraq & 1 & 26 \\
\hline Israel & 1 & 1 \\
\hline Italy & 4 & 4 \\
\hline Iran & 1 & 9 \\
\hline Netherlands & 1 & 1 \\
\hline Pakistan & 1 & 1 \\
\hline Peru & 1 & 1 \\
\hline Portugal & 1 & 1 \\
\hline Qatar & 1 & 1 \\
\hline UK & 3 & 8 \\
\hline USA & 11 & 14 \\
\hline Turkey & 2 & 3 \\
\hline Switzerland & 1 & 1 \\
\hline Korea & 1 & 4 \\
\hline Total & 81 & 577 \\
\hline
\end{tabular}

reported from China $(28 / 81,34.6 \%)$, almost one-sixth were from the USA $(11 / 81,13.6 \%)$, accounting together for about half of the studies $(39 / 81,48.1 \%)$ included in our review. The global distribution of studies is shown in Table 1 and S1 Fig.

Table 1. Distribution of studies ( $N=81$ ) and reinfection cases $(N=577)$ according to country of 
medRxiv preprint doi: https://doi.org/10.1101/2021.07.22.21260972; this version posted July 25, 2021. The copyright holder for this preprint (which was not certified by peer review) is the author/funder, who has granted medRxiv a license to display the preprint in perpetuity.

All rights reserved. No reuse allowed without permission.

\section{1}

172

577 cases, approximately one-third of the cases $(n=179,31.0 \%)$ were reported to have at least one comorbidity. Reports of having a positive contact history with a close contact or a family member with COVID-19 were found in 87 (15.1\%) cases (S2 Table and Table 2). Across 76 studies, the average reported time duration between first infection and reinfection was $63.6 \pm$ 48.9 days (range $11.0-210.0$ days).

Table 2. Demographics of Patients.

\begin{tabular}{lc}
\hline Variable & Mean Proportion (\%) \\
\hline Age (Years) & $46.2 \pm 18.9$ years (range 3.0-91.0 \\
Gender & years) \\
Male & $264(45.8)$ \\
Female & $310(53.7)$ \\
Not specified & $3(0.5)$ \\
Contact History Positive & $87(15.1)$ \\
Underlying Comorbidities & $179(31.0)$ \\
Average time duration between & $63.6 \pm 48.9$ days (range $11.0-210.0$ \\
first infection and reinfection & days) \\
&
\end{tabular}

\section{Clinical features during first infection and reinfection}

Around three-fourth of our cases were categorized as being mildly symptomatic with only 10 cases being classified as severe to critical by their respective studies for disease severity in the first infection. The total number of asymptomatic cases during the first infection was 53 (9.2\%) with an increase to 184 (31.9\%) cases noted during reinfection (S2 Table). Tian M et al.,[72] reported the highest number of asymptomatic cases (20/577, 3.5\%) during the first infection whereas An J et al.,[17] with 27 cases (4.7\%) reported the highest number of asymptomatic cases during reinfection. The presence of antibodies was also reported for the total 577 cases, 
medRxiv preprint doi: https://doi.org/10.1101/2021.07.22.21260972; this version posted July 25, 2021. The copyright holder for this preprint (which was not certified by peer review) is the author/funder, who has granted medRxiv a license to display the preprint in perpetuity.

All rights reserved. No reuse allowed without permission.

wherein $323(56.0 \%)$ and 364 (63.0\%) cases were detected to be positive during first infection and reinfection, respectively.

The most common presenting symptoms amongst patients in the first infection were fever $(n=239,41.4 \%)$ and cough $(n=201,34.8 \%)$, which then accounted for $36.4 \%(n=210)$ and $34.8 \%$ $(n=201)$ of cases, respectively, during reinfection. Myalgia was reported in $80(13.9 \%)$ cases during first infection which increased to $88(15.3 \%)$ cases during reinfection. The frequencies and odds ratio of other reported signs and symptoms are listed in Fig 2.

\section{Fig 2. Clinical features of First Infection and Reinfection ( $N=577$ )}

Regarding the radiological imaging during first infection of the 577 cases, almost one-quarter $(146 / 577,25.3 \%)$ had not reported, or did not have, any kind of chest imaging done. Out of those who reported, only 25 (4.3\%) cases had a normal finding whereas 295 (51.1\%) cases reported an abnormality with Chen et al., [27] reporting the highest occurrence of radiological abnormalities (70 out of 81 cases, $86.4 \%$ ).

\section{Management of first infection and reinfection}

The most administered treatment, as reported by the study results, was antiviral therapy accounting for $44.5 \%(n=257)$ and $43.0 \%(n=248)$ of cases during first infection and reinfection, respectively. Administration of antibiotics was lower at $14.4 \%(n=83)$ and $13.2 \%(n=76)$ for first infection and reinfection respectively (Fig 3).

\section{Fig 3. Management of First Infection and Reinfection ( $N=577$ )}


medRxiv preprint doi: https://doi.org/10.1101/2021.07.22.21260972; this version posted July 25, 2021. The copyright holder for this preprint (which was not certified by peer review) is the author/funder, who has granted medRxiv a license to display the preprint in perpetuity.

All rights reserved. No reuse allowed without permission.

199

200

201

202

203

204

205

206

207

208

209

210

211

212

213

214

215

216

\section{Outcomes of first infection and reinfection}

218 Complete recovery rate after reinfection stood at $97.9 \%$ (565 cases) with a total of 10 (1.8\%)

In the study by He et al. [42], $60 \%$ of patients were administered steroids during both infections, which was reported to be the highest use of steroids amongst studies reported to date. However, in our data, the overall use of steroids stood at $16.6 \%(n=96)$ and $12.1 \%(n=70)$ during the respective infections. Traditional Chinese medicine and interferon administration were reported at $13.9 \%(n=80)$ and $10.7 \%(n=62)$ during the first infection and $26.7 \%(n=154)$ and $7.6 \%(n=44)$ during reinfections, respectively.

Lastly, our results show that the use of low flow oxygen stood at $6.1 \%(n=35)$ of cases during the first infection which then doubled to $12.3 \%(n=71)$ of cases during reinfection (Fig 3). Out of the total studies, reports of ICU admission and mechanical ventilation was relatively low being $0.5 \%(n=3)$ and $0.3 \%(n=2)$ during first infection, respectively, compared to $1.7 \%(n=10)$ and $1.6 \%(n=9)$ during reinfection, respectively. This was contradictory to a higher number of asymptomatic cases observed in the reinfection phase, implicating for a possible need of an Individual Patient Data (IPD) analysis in future studies.

Comparable odds of symptomatic presentation (OR:0.93, $95 \% \mathrm{Cl}: 0.74-1.17$ ) and management (OR:0.90, 95\% Cl: 0.63-1.29) were observed in the first infection compared to reinfection when meta-analyzed, as shown in Fig 2 and Fig 3. Although a higher event of management was observed in the first infection, due to the individual weight of the studies, the overall OR favored first infection and was less than 1.

deaths. The outcome status was unknown for 2 cases (0.3\%) (S2 Table). The eight expired cases 
medRxiv preprint doi: https://doi.org/10.1101/2021.07.22.21260972; this version posted July 25, 2021. The copyright holder for this preprint (which was not certified by peer review) is the author/funder, who has granted medRxiv a license to display the preprint in perpetuity.

All rights reserved. No reuse allowed without permission.

220

221

222

223

224

225

226

227

228

229

230

231

232

233

234

235

236

237

238

239

240

were elderly (72-91 years old; 1 male and 7 females) and 2 cases were middle-aged adults (44 and 54 years old; both males). Seven cases had comorbidities involving multiple organ systems whilst three suffered from hypertension and the remaining one had an underlying malignancy. Respiratory failure was the most common cause of death (Seven out of ten deaths).

\section{Pediatric (0-19 years) reinfection cases}

Out of 577 cases, disaggregated data for 24 pediatric (0-18 years) cases was available.

Disaggregation reported positive contact histories in 7 cases (29.2\%) with only 1 (4.2\%)

reporting a comorbidity. A total of 7 cases (29.2\%) were asymptomatic followed by fever $(n=4$, $16.7 \%)$ and cough $(n=3,12.5 \%)$ in first infection whereas during reinfection, asymptomatic presentation $(n=7,29.2 \%)$ was followed by cough $(n=4,16.7 \%)$ and then fever $(n=3,12.5 \%)$.

With 9 abnormal chest X-ray findings (37.5\%), the most frequently used management modalities during first infection and reinfection were anti-viral $(n=12)$ and traditional Chinese Medicine $(n=12)$, respectively. All patient outcomes were reported as recovered.

\section{Quality assessment of included studies}

Seventy-two studies were determined to be of good quality while nine studies were of fair quality (S3 Table). Studies were primarily downgraded for unclear study objectives[63], incomplete case definition[16, $28,48,66,67,70,77,83]$, non-consecutive subject recruitment[19, 27, 30, 34, 38, 39, 44-46, 49, 71, 79, 80, 86, 90], incomparable subjects[79], inadequate length of follow-up[43, 63], inadequate description of statistical methods[39, 46, $80]$ and inadequate description of results $[39,78]$. The most common cause for downgrading studies was non-consecutive recruitment which raised concerns that the included sample could 
medRxiv preprint doi: https://doi.org/10.1101/2021.07.22.21260972; this version posted July 25, 2021. The copyright holder for this preprint (which was not certified by peer review) is the author/funder, who has granted medRxiv a license to display the preprint in perpetuity.

All rights reserved. No reuse allowed without permission.

241 be biased towards a more severe presentation or included more individuals undergoing routine

242 screening.

\section{Discussion}

244 Both the developing and developed world are still battling the spread of COVID-19. A major

245 concern that needs to be addressed is the appearance of reinfections in previously recovered

246 COVID-19 patients.

247 Our review is the first, and largest, systematic review covering COVID-19 reinfection cases from over 22 countries, raising questions concerning vaccination and exploring a specific set of determinants that can facilitate reinfection in recovered individuals. Similar systematic reviews on COVID-19 reinfection have been conducted previously $[92,93]$ but none of those studies, or

251 any conducted so far in the literature, have been as extensive as this review in terms of

252 analyzing the clinical information between first infection and reinfection whilst covering a wide

253 range of international and regional databases. One of the major strengths of this review is the

254 substantial timeframe that it covers: January 2020 to March 2021, spanning a total of 81 studies

255 with a widespread distribution of High-Income Countries (HICS) and LMICs to differentiate

256 features of reinfection cases as per different settings. In addition, adult cases were separated

257 from pediatric cases to differentiate between clinical features and identify the optimal

258 treatment management strategies as per varying age groups. Furthermore, case reports and

259 case series included in our study were quality assessed with 72 out of 81 studies reported to be

260 of good quality. An analysis of only pediatric reinfection cases was also conducted in this

261 review. Good prognosis and lower morbidity were reported in the pediatric cases, similar to the 
medRxiv preprint doi: https://doi.org/10.1101/2021.07.22.21260972; this version posted July 25, 2021. The copyright holder for this preprint (which was not certified by peer review) is the author/funder, who has granted medRxiv a license to display the preprint in perpetuity.

All rights reserved. No reuse allowed without permission.

262

263

264

265

266

267

268

269

270

271

272

273

274

275

276

277

278

279

280

281

282

283

general COVID-19 disease course in the pediatric population[94]. Therefore, we suggest public health campaigns targeting people of younger age as they are at similar risk of reinfection as adults, to ensure elimination of complacency and enforcement of protective measures, such as face masks and social distancing.

A broad distribution was seen amongst severity of first infection compared to reinfection as well as management and number of symptomatic cases. The most reported clinical symptoms in our review were fever (41.4\%) and cough (34.8\%) in first infection with a frequency of $36.4 \%$ cases with fever and $34.8 \%$ cases with cough in reinfection, respectively. These findings are similar to a trend observed in the review on reinfections by Gidari et al.[95] In addition, the number of asymptomatic cases in our review increased from $9.2 \%$ in first infection to $31.9 \%$ in second infection, similar to findings reported in the review by Gidari et al[95]. On the contrary, a higher requirement of ICU admission and mechanical ventilation was observed during reinfection in our review. A meta-analysis analysis of 123 cases by Vancsa et al[96] showed that the second episode of SARS-COV-2 infection is more severe than the first if it happens within 60 days of the first positive PCR. This deems the necessity of IPD analysis as many of the larger case series report more severe cases which might skew the overall findings. A total of 10 deaths were reported in this review, all amongst reinfection cases. In all 10 cases, several comorbidities were present and all patients who were classified as the most severe were of older age, a similar trend seen in a study by Wang et al.[97] Most of these patients died due to respiratory complications; similar effects of these comorbidities can be seen in other respiratory illnesses such as MERS-CoV[98]. The results from this review suggest that comorbidities and age play a major role in the outcome of critical patients. 
medRxiv preprint doi: https://doi.org/10.1101/2021.07.22.21260972; this version posted July 25, 2021. The copyright holder for this preprint (which was not certified by peer review) is the author/funder, who has granted medRxiv a license to display the preprint in perpetuity.

All rights reserved. No reuse allowed without permission.

284 The time duration between first infection and reinfection has been a source of debate. Alinaghi et al. in their systematic review[93] estimated that antibodies from natural infection lasted 40 days, after which the chances of reinfection increased. The average time duration between first infection and reinfection in our review was 63.6 days. Wang et al. in their review noted it to be 76 days[99] whereas Manish et al. in their review[100] observed a lengthier duration of median COVID-19 reinfection, especially considering waning antibodies.

Another observation made in our review was differences in the presence of antibodies during IgA levels and neutralizing antibodies started declining after 30 days. In our review, 56.0\% and 
medRxiv preprint doi: https://doi.org/10.1101/2021.07.22.21260972; this version posted July 25, 2021. The copyright holder for this preprint (which was not certified by peer review) is the author/funder, who has granted medRxiv a license to display the preprint in perpetuity.

All rights reserved. No reuse allowed without permission.

did not confer total immunity and a second infection by a different variant was possible with the second infection being more severe than the first. Even though most of the studies in our review predated the announcements of the new variants, however, given the ability of the virus to mutate at a rapid pace, some reinfection cases reported in our study could be due to the variants which would have resulted in more severity of reinfection. Whether waning antibodies or new variants were the source of reinfection is a question that should be explored further in future studies.

A recent systematic review by Azam et al. looked at the incidence of SARS-COV-2 positivity in patients who had recovered from COVID-19 [103]. They noted that younger patients and those with a longer initial infection were more likely to have recurrent positivity. A similar systematic review by Manish et al. on the assessment of SARS-COV-2 mutations in reinfections and persistent infections[100] noted it to be challenging to differentiate between reinfection and persistent recurrent infection, concluding that the former happened in immunocompetent individuals and the latter happened in immunocompromised individuals. Furthermore, this phenomenon was associated with a faster viral evolution and mutation resulting in the creation of new variants. Lastly, another systematic review by Hoang on the risk factors associated with re-positive viral RNA after recovery from COVID-19 [104] postulated that the re-positive viral RNA seen in their review likely added to the evidence that viral relapse was a cause of COVID19 recurrence.

This review has some limitations, such as the small sample sizes analyzed from each country except for China that had $73 \%(n=423)$ of the total included cases. The majority of these cases were reported from Wuhan or the Hubei province, where the gross domestic product per 
medRxiv preprint doi: https://doi.org/10.1101/2021.07.22.21260972; this version posted July 25, 2021. The copyright holder for this preprint (which was not certified by peer review) is the author/funder, who has granted medRxiv a license to display the preprint in perpetuity.

All rights reserved. No reuse allowed without permission.

capita is less than half of that of Beijing and Shanghai[105] . Therefore, the findings of studies from China may be generalizable to the socioeconomic and health development status of other middle-income countries and not to high-income nations. This review can be improved by sampling larger series and including IPD, if available, to predict the outcome of COVID-19 illness based off epidemiological trends dramatically reducing hospitalization time, given the lack of sufficient healthcare resources in low-middle income countries. Therefore, a selection bias remains when considering LMICs where admitted hospital patients could be in a more critical state reporting a higher mortality rate.

Our review on reinfections in COVID-19 also comes at a pertinent time as countries, especially the developing world, suffer a repeated wave of infection[106]. At this time, public health initiatives aimed at removing complacency are the need of hour, and one of the key messages that needs to be given is that reinfection is a reality and vaccines along with social distancing remain the key in fighting the pandemic. A recently published online longitudinal survey [107] in 23 countries of high, middle and low income, across 4 continents with over 1 million participants provides hope in this regard, as it identified that the intention to vaccinate amongst the general public is at an all-time high, with the major issue not being vaccine hesitancy but a shortage of vaccines. A recent report of a 4 month surveillance of mass immunization in Israel [108] notes two doses of the Pfizer BioNTech mRNA COVId-19 vaccine to be highly effective (95.3\%; 95\% CI 94.9-95.7) against SARS-CoV-2 infection and mitigated COVID-19-related hospitalizations, severe disease, and death, including those caused by variants including the B.1.1.7 SARS-CoV-2. Whilst the world is still under process of getting vaccinated, data needs to be collected on patients in the long run to analyze whether 
medRxiv preprint doi: https://doi.org/10.1101/2021.07.22.21260972; this version posted July 25, 2021. The copyright holder for this preprint (which was not certified by peer review) is the author/funder, who has granted medRxiv a license to display the preprint in perpetuity.

All rights reserved. No reuse allowed without permission.

350

vaccination has any correlation with reinfection cases and further investigate the average time needed by the various vaccines to achieve their desired efficacies. We hope that governments across the world seize this moment and take steps to ensure equitable distribution of vaccines so that the world can finally step out of the long shadow cast by the COVID-19 pandemic.

\section{Conclusion}

COVID-19 first infections and reinfections observe a similar clinical spectrum and management regimen with a slightly higher severity reported during reinfection in the form of requirement for mechanical ventilation and ICU admission. There lies a need for much closer scrutiny of reinfections globally with individual patient data analysis to derive determinants of reinfection incidence and disposition to a severe infection.

\section{Acknowledgements: None.}

\section{References}

1. COVID-19 Dashboard [Internet]. Johns Hopkins University. 2021 [cited 20th May 2021].

Available from: https://coronavirus.jhu.edu/map.html.

2. Fergie J, Srivastava A. Immunity to SARS-CoV-2: Lessons Learned. Front Immunol. 2021;12:654165. Epub 2021/04/06. doi: 10.3389/fimmu.2021.654165. PubMed PMID:

33815415; PubMed Central PMCID: PMCPMC8018176.

3. Costa AOC, Neto HdCA, Nunes APL, de Castro RD, de Almeida RN. COVID-19: Is reinfection possible? EXCLI Journal. 2021;20:522-36.

4. Khoshkam Z, Aftabi Y, Stenvinkel P, Paige Lawrence B, Rezaei MH, Ichihara G, et al. Recovery scenario and immunity in COVID-19 disease: A new strategy to predict the potential of 
medRxiv preprint doi: https://doi.org/10.1101/2021.07.22.21260972; this version posted July 25, 2021. The copyright holder for this preprint (which was not certified by peer review) is the author/funder, who has granted medRxiv a license to display the preprint in perpetuity.

All rights reserved. No reuse allowed without permission.

371 reinfection. J Adv Res. 2021. Epub 2021/02/02. doi: 10.1016/j.jare.2020.12.013. PubMed PMID:

372 33520309; PubMed Central PMCID: PMCPMC7832464.

373 5. Prevost J, Finzi A. The great escape? SARS-CoV-2 variants evading neutralizing

374 responses. Cell Host Microbe. 2021;29(3):322-4. Epub 2021/03/12. doi:

375 10.1016/j.chom.2021.02.010. PubMed PMID: 33705702; PubMed Central PMCID:

376 PMCPMC7945862.

377 6. Wang Z, Schmidt F, Weisblum Y, Muecksch F, Barnes CO, Finkin S, et al. mRNA vaccine-

378 elicited antibodies to SARS-CoV-2 and circulating variants. Nature. 2021. Epub 2021/02/11. doi:

379 10.1038/s41586-021-03324-6. PubMed PMID: 33567448.

$3807 . \quad$ CDC. Reinfection with COVID-19. https://www.cdc.gov/coronavirus/2019-ncov/your-

381 health/reinfection.html.2020.

382 8. Tillett RL, Sevinsky JR, Hartley PD, Kerwin H, Crawford N, Gorzalski A, et al. Genomic

383 evidence for reinfection with SARS-CoV-2: a case study. Lancet Infect Dis. 2021;21(1):52-8. Epub

384 2020/10/16. doi: 10.1016/S1473-3099(20)30764-7. PubMed PMID: 33058797; PubMed Central

385 PMCID: PMCPMC7550103.

$3869 . \quad$ Iwasaki A. What reinfections mean for COVID-19. The Lancet Infectious Diseases.

387 2021;21(1):3-5. doi: 10.1016/s1473-3099(20)30783-0.

388 10. Gomez CE, Perdiguero B, Esteban M. Emerging SARS-CoV-2 Variants and Impact in

389 Global Vaccination Programs against SARS-CoV-2/COVID-19. Vaccines (Basel). 2021;9(3). Epub

390 2021/04/04. doi: 10.3390/vaccines9030243. PubMed PMID: 33799505; PubMed Central

391 PMCID: PMCPMC7999234. 
medRxiv preprint doi: https://doi.org/10.1101/2021.07.22.21260972; this version posted July 25, 2021. The copyright holder for this preprint (which was not certified by peer review) is the author/funder, who has granted medRxiv a license to display the preprint in perpetuity.

All rights reserved. No reuse allowed without permission.

392

393

394

395

396

397

398

399

400

401

402

403

404

405

406

407

408

409

410

411

412

413

11. Welfare MoHAF. Genome Sequencing by INSACOG shows variants of concern and a Novel variant in India. https://pib.gov.in/PressReleaselframePage.aspx?PRID=1707177: PIB Delhi; 2021.

12. Abdallah H, Porterfield F, Fajgenbaum D. Symptomatic relapse and long-term sequelae of COVID-19 in a previously healthy 30-year-old man. BMJ Case Rep. 2020;13(12):e239825-e. Epub 2020/12/16. doi: 10.1136/bcr-2020-239825. PubMed PMID: 33318288; PubMed Central PMCID: PMCPMC7736956.

13. Adrielle Dos Santos L, Filho PGG, Silva AMF, Santos JVG, Santos DS, Aquino MM, et al. Recurrent COVID-19 including evidence of reinfection and enhanced severity in thirty Brazilian healthcare workers. J Infect. 2021;82(3):399-406. Epub 2021/02/17. doi:

10.1016/j.jinf.2021.01.020. PubMed PMID: 33589297; PubMed Central PMCID: PMCPMC7880834.

14. Ak R, Yilmaz E, Seyhan AU, Doganay F. Recurrence of COVID-19 Documented with RTPCR. J Coll Physicians Surg Pak. 2021;30(1):S26-S8. Epub 2021/03/03. doi:

10.29271/jcpsp.2021.01.S26. PubMed PMID: 33650420.

15. Ali AM, Ali KM, Fatah MH, Tawfeeq HM, Rostam HM. SARS-CoV-2 Reinfection in Patients Negative for Immunoglobulin G Following Recovery from COVID-19. medRxiv; 2020. p. 2020.11.20.20234385-2020.11.20.

16. Alonso FOM, Sabino BD, Guimaraes M, Varella RB. Recurrence of SARS-CoV-2 infection with a more severe case after mild COVID-19, reversion of RT-qPCR for positive and late antibody response: Case report. J Med Virol. 2021;93(2):655-6. Epub 2020/08/17. doi: 10.1002/jmv.26432. PubMed PMID: 32797634; PubMed Central PMCID: PMCPMC7436374. 
medRxiv preprint doi: https://doi.org/10.1101/2021.07.22.21260972; this version posted July 25, 2021. The copyright holder for this preprint (which was not certified by peer review) is the author/funder, who has granted medRxiv a license to display the preprint in perpetuity.

All rights reserved. No reuse allowed without permission.

414 17. An J, Liao X, Xiao T, Qian S, Yuan J, Ye H, et al. Clinical characteristics of recovered

415 COVID-19 patients with re-detectable positive RNA test. Ann Transl Med. 2020;8(17):1084.

416 Epub 2020/11/05. doi: 10.21037/atm-20-5602. PubMed PMID: 33145303; PubMed Central

417 PMCID: PMCPMC7575971.

418 18. Arteaga-Livias K, Panduro-Correa V, Pinzas-Acosta K, Perez-Abad L, Pecho-Silva S,

419 Espinoza-Sanchez F, et al. COVID-19 reinfection? A suspected case in a Peruvian patient. Travel

420 Med Infect Dis. 2021;39(Jan-Feb 2021):101947. Epub 2020/12/12. doi:

421 10.1016/j.tmaid.2020.101947. PubMed PMID: 33307196; PubMed Central PMCID:

422 PMCPMC7723440.

423 19. Atici S, Ek OF, Yildiz MS, Sikgenc MM, Guzel E, Soysal A. Symptomatic recurrence of

424 SARS-CoV-2 infection in healthcare workers recovered from COVID-19. J Infect Dev Ctries.

425 2021;15(1):69-72. Epub 2021/02/12. doi: 10.3855/jidc.14305. PubMed PMID: 33571147.

426 20. Bellanti F, Lo Buglio A, Custodero G, Barbera L, Minafra G, Montrano M, et al. Fatal

427 relapse of COVID-19 after recovery? A case report of an older Italian patient. J Infect.

428 2021;82(1):e49-e51. Epub 2020/12/20. doi: 10.1016/j.jinf.2020.12.009. PubMed PMID:

429 33340595; PubMed Central PMCID: PMCPMC7834308.

430 21. Bellesso M, Bruniera FR, Trunkel AT, Nicodemo IP. Second COVID-19 infection in a

431 patient with multiple myeloma in Brazil - reinfection or reactivation? Hematol Transfus Cell

432 Ther. 2021;43(1):109-11. Epub 2021/01/12. doi: 10.1016/j.htct.2020.12.002. PubMed PMID:

433 33423984; PubMed Central PMCID: PMCPMC7837121. 
medRxiv preprint doi: https://doi.org/10.1101/2021.07.22.21260972; this version posted July 25, 2021. The copyright holder for this preprint (which was not certified by peer review) is the author/funder, who has granted medRxiv a license to display the preprint in perpetuity.

All rights reserved. No reuse allowed without permission.

434 22. Bongiovanni M. COVID-19 reinfection in a healthcare worker. J Med Virol.

435 2020:jmv.26565-jmv. Epub 2020/09/30. doi: 10.1002/jmv.26565. PubMed PMID: 32990954;

436 PubMed Central PMCID: PMCPMC7537129.

437 23. Bonifacio LP, Pereira APS, Araujo D, Balbao V, Fonseca B, Passos ADC, et al. Are SARS-

438 CoV-2 reinfection and Covid-19 recurrence possible? a case report from Brazil. Rev Soc Bras

439 Med Trop. 2020;53:e20200619. Epub 2020/09/24. doi: 10.1590/0037-8682-0619-2020.

440 PubMed PMID: 32965458; PubMed Central PMCID: PMCPMC7508196.

441 24. Cao H, Ruan L, Liu J, Liao W. The clinical characteristic of eight patients of COVID-19 with

442 positive RT-PCR test after discharge. J Med Virol. 2020;92(10):2159-64. Epub 2020/05/16. doi:

443

10.1002/jmv.26017. PubMed PMID: 32410245; PubMed Central PMCID: PMCPMC7272974.

444 25. Chan PKS, Lui G, Hachim A, Ko RLW, Boon SS, Li T, et al. Serologic Responses in Healthy

445 Adult with SARS-CoV-2 Reinfection, Hong Kong, August 2020. Emerg Infect Dis.

446

2020;26(12):3076-8. Epub 2020/10/23. doi: 10.3201/eid2612.203833. PubMed PMID:

447 33089772; PubMed Central PMCID: PMCPMC7706979.

448 26. Chen D, Xu W, Lei Z, Huang Z, Liu J, Gao Z, et al. Recurrence of positive SARS-CoV-2 RNA

449 in COVID-19: A case report. Int J Infect Dis. 2020;93(Apr):297-9. Epub 2020/03/10. doi:

450 10.1016/j.ijid.2020.03.003. PubMed PMID: 32147538; PubMed Central PMCID:

$451 \quad$ PMCPMC7129213.

452 27. Chen J, Xu X, Hu J, Chen Q, Xu F, Liang H, et al. Clinical course and risk factors for

453 recurrence of positive SARS-CoV-2 RNA: a retrospective cohort study from Wuhan, China. Aging

454 (Albany NY). 2020;12(17):16675-89. Epub 2020/09/11. doi: 10.18632/aging.103795. PubMed

PMID: 32909961; PubMed Central PMCID: PMCPMC7521537. 
medRxiv preprint doi: https://doi.org/10.1101/2021.07.22.21260972; this version posted July 25, 2021. The copyright holder for this preprint (which was not certified by peer review) is the author/funder, who has granted medRxiv a license to display the preprint in perpetuity.

All rights reserved. No reuse allowed without permission.

456

457

458

459

460

461

462

463

464

465

466

467

468

469

470

471

472

473

474

475

476

28. Colson P, Finaud M, Levy N, Lagier JC, Raoult D. Evidence of SARS-CoV-2 re-infection with a different genotype. J Infect. 2021;82(4):84-123. Epub 2020/11/19. doi:

10.1016/j.jinf.2020.11.011. PubMed PMID: 33207255; PubMed Central PMCID:

PMCPMC7666873.

29. Coppola A, Annunziata A, Carannante N, Di Spirito V, Fiorentino G. Late Reactivation of SARS-CoV-2: A Case Report. Front Med (Lausanne). 2020;7:531. Epub 2020/09/26. doi:

10.3389/fmed.2020.00531. PubMed PMID: 32974374; PubMed Central PMCID:

PMCPMC7468504.

30. de Brito CAA, Lima PMA, de Brito MCM, de Oliveira DB. Second Episode of COVID-19 in Health Professionals: Report of Two Cases. Int Med Case Rep J. 2020;13(Oct):471-5. Epub 2020/10/17. doi: 10.2147/IMCRJ.S277882. PubMed PMID: 33061670; PubMed Central PMCID: PMCPMC7537988.

31. Dou C, Xie X, Peng Z, Tang H, Jiang Z, Zhong Z, et al. A case presentation for positive SARS-CoV-2 RNA recurrence in a patient with a history of type 2 diabetes that had recovered from severe COVID-19. Diabetes Res Clin Pract. 2020;166:108300. Epub 2020/07/15. doi: 10.1016/j.diabres.2020.108300. PubMed PMID: 32663490; PubMed Central PMCID: PMCPMC7354258.

32. Du HW, Chen JN, Pan XB, Chen XL, Yixian Z, Fang SF, et al. Prevalence and outcomes of re-positive nucleic acid tests in discharged COVID-19 patients. Eur J Clin Microbiol Infect Dis. 2021;40(2):413-7. Epub 2020/09/01. doi: 10.1007/s10096-020-04024-1. PubMed PMID: 32865669; PubMed Central PMCID: PMCPMC7456660. 
medRxiv preprint doi: https://doi.org/10.1101/2021.07.22.21260972; this version posted July 25, 2021. The copyright holder for this preprint (which was not certified by peer review) is the author/funder, who has granted medRxiv a license to display the preprint in perpetuity.

All rights reserved. No reuse allowed without permission.

477 33. Duggan NM, Ludy SM, Shannon BC, Reisner AT, Wilcox SR. Is novel coronavirus 2019

478 reinfection possible? Interpreting dynamic SARS-CoV-2 test results. Am J Emerg Med.

479 2021;39:256 e1- e3. Epub 2020/07/25. doi: 10.1016/j.ajem.2020.06.079. PubMed PMID:

480 32703607; PubMed Central PMCID: PMCPMC7335242.

481 34. Fu W, Chen Q, Wang T. Letter to the Editor: Three cases of redetectable positive SARS-

482 CoV-2 RNA in recovered COVID-19 patients with antibodies. J Med Virol. 2020;92(11):2298-301.

483

Epub 2020/05/06. doi: 10.1002/jmv.25968. PubMed PMID: 32369214; PubMed Central PMCID:

484

PMCPMC7267393.

485

35. Gao G, Zhu Z, Fan L, Ye S, Huang Z, Shi Q, et al. Absent immune response to SARS-CoV-2

486

in a 3-month recurrence of coronavirus disease 2019 (COVID-19) case. Infection. 2021;49(1):57-

487

61. Epub 2020/07/30. doi: 10.1007/s15010-020-01485-6. PubMed PMID: 32725596; PubMed

488

Central PMCID: PMCPMC7386381.

489

36. Goldman JD, Wang K, Röltgen K, Nielsen SCA, Roach JC, Naccache SN, et al. Reinfection

490 with SARS-CoV-2 and Failure of Humoral Immunity: A case report. medRxiv; 2020.

491 37. Gousseff M, Penot P, Gallay L, Batisse D, Benech N, Bouiller K, et al. Clinical recurrences

492 of COVID-19 symptoms after recovery: Viral relapse, reinfection or inflammatory rebound? J

493 Infect. 2020;81(5):816-46. Epub 2020/07/04. doi: 10.1016/j.jinf.2020.06.073. PubMed PMID:

494 32619697; PubMed Central PMCID: PMCPMC7326402 interest to declare regarding this subject.

495 This work had no financial support.

496 38. Gupta V, Bhoyar RC, Jain A, Srivastava S, Upadhayay R, Imran M, et al. Asymptomatic

497 reinfection in two healthcare workers from India with genetically distinct SARS-CoV-2. Clin 
medRxiv preprint doi: https://doi.org/10.1101/2021.07.22.21260972; this version posted July 25, 2021. The copyright holder for this preprint (which was not certified by peer review) is the author/funder, who has granted medRxiv a license to display the preprint in perpetuity.

All rights reserved. No reuse allowed without permission.

498

499

500

501

502

503

504

505

506

507

508

509

510

511

512

513

514

515

516

517

Infect Dis. 2020. Epub 2020/09/24. doi: 10.1093/cid/ciaa1451. PubMed PMID: 32964927;

PubMed Central PMCID: PMCPMC7543380.

39. Habibzadeh P, Sajadi MM, Emami A, Karimi MH, Yadollahie M, Kucheki M, et al. Rate of re-positive RT-PCR test among patients recovered from COVID-19. Biochem Med (Zagreb).

2020;30(3):030401. Epub 2020/08/11. doi: 10.11613/BM.2020.030401. PubMed PMID:

32774117; PubMed Central PMCID: PMCPMC7394260.

40. Hanif M, Haider MA, Ali MJ, Naz S, Sundas F. Reinfection of COVID-19 in Pakistan: A First Case Report. Cureus. 2020;12(10):e11176. Epub 2020/12/03. doi: 10.7759/cureus.11176.

PubMed PMID: 33262913; PubMed Central PMCID: PMCPMC7689968.

41. Harrington D, Kele B, Pereira S, Couto-Parada X, Riddell A, Forbes S, et al. Confirmed

Reinfection with SARS-CoV-2 Variant VOC-202012/01. Clin Infect Dis. 2021. Epub 2021/01/10.

doi: 10.1093/cid/ciab014. PubMed PMID: 33421056; PubMed Central PMCID:

PMCPMC7929017.

42. He S, Sun W, Zhou K, Hu M, Liu C, Xie L, et al. Clinical Characteristics Analysis of the "Repositive" Discharged COVID-19 Pneumonia Patients in Wuhan, China. 2020. doi:

\subsection{3/rs.3.rs-28667/v1.}

43. Huang J, Zheng L, Li Z, Hao S, Ye F, Chen J, et al. Recurrence of SARS-CoV-2 PCR positivity in COVID-19 patients: A single center experience and potential implications. medRxiv; 2020. p. 2020.05.06.20089573-2020.05.06.

44. Kapoor R, Nair RK, Nayan N, Bhalla S, Singh J. Reinfection or Reactivation of Coronavirus19 in Patients with Hematologic Malignancies: Case Report Series. SN Compr Clin Med. 
medRxiv preprint doi: https://doi.org/10.1101/2021.07.22.21260972; this version posted July 25, 2021. The copyright holder for this preprint (which was not certified by peer review) is the author/funder, who has granted medRxiv a license to display the preprint in perpetuity.

All rights reserved. No reuse allowed without permission.

519

520

521

522

523

524

525

526

527

528

529

530

531

532

533

534

535

536

537

538

2021;3(2):1-5. Epub 2021/02/16. doi: 10.1007/s42399-021-00790-x. PubMed PMID: 33585797;

PubMed Central PMCID: PMCPMC7873512.

45. Lafaie L, Celarier T, Goethals L, Pozzetto B, Grange S, Ojardias E, et al. Recurrence or

Relapse of COVID-19 in Older Patients: A Description of Three Cases. J Am Geriatr Soc.

2020;68(10):2179-83. Epub 2020/07/09. doi: 10.1111/jgs.16728. PubMed PMID: 32638347;

PubMed Central PMCID: PMCPMC7361461.

46. Lan L, Xu D, Ye G, Xia C, Wang S, Li Y, et al. Positive RT-PCR Test Results in Patients

Recovered From COVID-19. JAMA. 2020;323(15):1502-3. Epub 2020/02/28. doi:

10.1001/jama.2020.2783. PubMed PMID: 32105304; PubMed Central PMCID:

PMCPMC7047852.

47. Lancman G, Mascarenhas J, Bar-Natan M. Severe COVID-19 virus reactivation following treatment for B cell acute lymphoblastic leukemia. J Hematol Oncol. 2020;13(1):131. Epub 2020/10/04. doi: 10.1186/s13045-020-00968-1. PubMed PMID: 33008453; PubMed Central PMCID: PMCPMC7531062.

48. Larson D, Brodniak SL, Voegtly L, Cer RZ, Glang LA, Malagon FJ, et al. A Case of Early Reinfection with SARS-CoV-2. Clin Infect Dis. 2020. Epub 2020/09/20. doi: 10.1093/cid/ciaa1436. PubMed PMID: 32949240; PubMed Central PMCID: PMCPMC7543357.

49. Li J, Wei X, Tian W, Zou J, Wang Y, Xue W, et al. Clinical features of discharged COVID-19 patients with an extended SARS-CoV-2 RNA positive signal in respiratory samples. Virus Res. 2020;286:198047. Epub 2020/06/12. doi: 10.1016/j.virusres.2020.198047. PubMed PMID: 32522535; PubMed Central PMCID: PMCPMC7833058. 
medRxiv preprint doi: https://doi.org/10.1101/2021.07.22.21260972; this version posted July 25, 2021. The copyright holder for this preprint (which was not certified by peer review) is the author/funder, who has granted medRxiv a license to display the preprint in perpetuity.

All rights reserved. No reuse allowed without permission.

540 50. Li XJ, Zhang ZW, Zong ZY. A case of a readmitted patient who recovered from COVID-19

541 in Chengdu, China. Crit Care. 2020;24(1):152. Epub 2020/04/18. doi: 10.1186/s13054-020-

542 02877-8. PubMed PMID: 32299477; PubMed Central PMCID: PMCPMC7160612.

543 51. Li Y, Hu Y, Yu Y, Zhang X, Li B, Wu J, et al. Positive result of Sars-Cov-2 in faeces and

544 sputum from discharged patients with COVID-19 in Yiwu, China. J Med Virol. 2020;92(10):1938-

545 47. Epub 2020/04/21. doi: 10.1002/jmv.25905. PubMed PMID: 32311109; PubMed Central

546 PMCID: PMCPMC7264799.

547 52. Ling $Y, X u S B$, Lin $Y X$, Tian D, Zhu ZQ, Dai FH, et al. Persistence and clearance of viral RNA 548 in 2019 novel coronavirus disease rehabilitation patients. Chin Med J (Engl). 2020;133(9):1039-

43. Epub 2020/03/03. doi: 10.1097/CM9.0000000000000774. PubMed PMID: 32118639;

550

PubMed Central PMCID: PMCPMC7147278.

551

53. Liu F, Cai ZB, Huang JS, Yu WY, Niu HY, Zhang Y, et al. Positive SARS-CoV-2 RNA recurs

552

repeatedly in a case recovered from COVID-19: dynamic results from 108 days of follow-up.

553 Pathog Dis. 2020;78(4):31-. Epub 2020/06/28. doi: 10.1093/femspd/ftaa031. PubMed PMID:

554 32592396; PubMed Central PMCID: PMCPMC7337794.

555 54. Loconsole D, Passerini F, Palmieri VO, Centrone F, Sallustio A, Pugliese S, et al.

556 Recurrence of COVID-19 after recovery: a case report from Italy. Infection. 2020;48(6):965-7.

557 Epub 2020/05/18. doi: 10.1007/s15010-020-01444-1. PubMed PMID: 32415334; PubMed

558 Central PMCID: PMCPMC7228864.

$55955 . \quad$ Luo A. Positive SARS-Cov-2 test in a woman with COVID-19 at 22 days after hospital

560 discharge: A case report. Journal of Traditional Chinese Medical Sciences. 2020;7(4):413-7. doi:

$561 \quad 10.1016 / j . j t c m s .2020 .04 .001$. 
medRxiv preprint doi: https://doi.org/10.1101/2021.07.22.21260972; this version posted July 25, 2021. The copyright holder for this preprint (which was not certified by peer review) is the author/funder, who has granted medRxiv a license to display the preprint in perpetuity.

All rights reserved. No reuse allowed without permission.

562 56. Mei Q, Li J, Du R, Yuan X, Li M, Li J. Assessment of patients who tested positive for

563 COVID-19 after recovery. Lancet Infect Dis. 2020;20(9):1004-5. Epub 2020/07/10. doi:

564 10.1016/S1473-3099(20)30433-3. PubMed PMID: 32645295; PubMed Central PMCID:

565 PMCPMC7338012.

566 57. Moore JL, Ganapathiraju PV, Kurtz CP, Wainscoat B. A 63-Year-Old Woman with a

567 History of Non-Hodgkin Lymphoma with Persistent SARS-CoV-2 Infection Who Was

568 Seronegative and Treated with Convalescent Plasma. Am J Case Rep. 2020;21:e927812. Epub

569 2020/10/04. doi: 10.12659/AJCR.927812. PubMed PMID: 33009361; PubMed Central PMCID:

$570 \quad$ PMCPMC7542548.

571 58. Mulder M, van der Vegt D, Oude Munnink BB, GeurtsvanKessel CH, van de Bovenkamp J,

572 Sikkema RS, et al. Reinfection of SARS-CoV-2 in an immunocompromised patient: a case report.

573 Clin Infect Dis. 2020. Epub 2020/10/13. doi: 10.1093/cid/ciaa1538. PubMed PMID: 33043962;

574 PubMed Central PMCID: PMCPMC7665355.

575 59. Nachmias V, Fusman R, Mann S, Koren G. The first case of documented Covid-19

576 reinfection in Israel. IDCases. 2020;22:e00970. Epub 2020/10/09. doi:

577 10.1016/j.idcr.2020.e00970. PubMed PMID: 33029476; PubMed Central PMCID:

578 PMCPMC7528892.

579 60. Novoa W, Miller H, Mattar S, Faccini-Martinez AA, Rivero R, Serrano-Coll H. A first

580 probable case of SARS-CoV-2 reinfection in Colombia. Ann Clin Microbiol Antimicrob.

581 2021;20(1):7. Epub 2021/01/14. doi: 10.1186/s12941-020-00413-8. PubMed PMID: 33435982;

582 PubMed Central PMCID: PMCPMC7802059. 
medRxiv preprint doi: https://doi.org/10.1101/2021.07.22.21260972; this version posted July 25, 2021. The copyright holder for this preprint (which was not certified by peer review) is the author/funder, who has granted medRxiv a license to display the preprint in perpetuity.

All rights reserved. No reuse allowed without permission.

583

584

585

586

587

588

589

590

591

592

593

594

595

596

597

598

599

600

601

602

603

604

61. Pan L, Wang R, Yu N, Hu C, Yan J, Zhang X, et al. Clinical characteristics of re-hospitalized COVID-19 patients with recurrent positive SARS-CoV-2 RNA: a retrospective study. Eur J Clin Microbiol Infect Dis. 2021. Epub 2021/01/16. doi: 10.1007/s10096-020-04151-9. PubMed

PMID: 33447913; PubMed Central PMCID: PMCPMC7808928.

62. Parry J. Covid-19: Hong Kong scientists report first confirmed case of reinfection. BMJ. 2020;370:m3340. Epub 2020/08/28. doi: 10.1136/bmj.m3340. PubMed PMID: 32847834.

63. Patrocinio de Jesus R, Silva R, Aliyeva E, Lopes L, Portugalyan M, Antunes L, et al.

Reactivation of SARS-CoV-2 after Asymptomatic Infection while on High-Dose Corticosteroids.

Case Report. SN Compr Clin Med. 2020;2(11):1-4. Epub 2020/10/13. doi: 10.1007/s42399-020-

00548-x. PubMed PMID: 33043249; PubMed Central PMCID: PMCPMC7531809.

64. Prado-Vivar B, Becerra-Wong M, Guadalupe JJ, Marquez S, Gutierrez B, Rojas-Silva P, et al. A case of SARS-CoV-2 reinfection in Ecuador. Lancet Infect Dis. 2020. Epub 2020/11/27. doi: 10.1016/S1473-3099(20)30910-5. PubMed PMID: 33242475; PubMed Central PMCID:

PMCPMC7833993.

65. Salcin S, Fontem F. Recurrent SARS-CoV-2 infection resulting in acute respiratory distress syndrome and development of pulmonary hypertension: A case report. Respir Med Case Rep. 2021;33:101314. Epub 2020/12/15. doi: 10.1016/j.rmcr.2020.101314. PubMed PMID:

33312856; PubMed Central PMCID: PMCPMC7718582.

66. Selhorst P, Van lerssel S, Michiels J, Marien J, Bartholomeeusen K, Dirinck E, et al. Symptomatic SARS-CoV-2 reinfection of a health care worker in a Belgian nosocomial outbreak despite primary neutralizing antibody response. Clin Infect Dis. 2020. Epub 2020/12/15. doi: 10.1093/cid/ciaa1850. PubMed PMID: 33315049; PubMed Central PMCID: PMCPMC7799230. 
medRxiv preprint doi: https://doi.org/10.1101/2021.07.22.21260972; this version posted July 25, 2021. The copyright holder for this preprint (which was not certified by peer review) is the author/funder, who has granted medRxiv a license to display the preprint in perpetuity.

All rights reserved. No reuse allowed without permission.

605 67. Selvaraj V, Herman K, Dapaah-Afriyie K. Severe, Symptomatic Reinfection in a Patient

606 with COVID-19. R I Med J (2013). 2020;103(10):24-6. Epub 2020/11/12. PubMed PMID:

60733172223.

608 68. Sharma R, Sardar S, Mohammad Arshad A, Ata F, Zara S, Munir W. A Patient with

609 Asymptomatic SARS-CoV-2 Infection Who Presented 86 Days Later with COVID-19 Pneumonia

610 Possibly Due to Reinfection with SARS-CoV-2. Am J Case Rep. 2020;21:e927154. Epub

611 2020/12/02. doi: 10.12659/AJCR.927154. PubMed PMID: 33257644; PubMed Central PMCID:

612 PMCPMC7718490.

613 69. Sicsic I, Jr., Chacon AR, Zaw M, Ascher K, Abreu A, Chediak A. A case of SARS-CoV-2

614 reinfection in a patient with obstructive sleep apnea managed with telemedicine. BMJ Case

615 Rep. 2021;14(2):240496-. Epub 2021/02/03. doi: 10.1136/bcr-2020-240496. PubMed PMID:

616 33526540; PubMed Central PMCID: PMCPMC7852971.

617 70. Song KH, Kim DM, Lee H, Ham SY, Oh SM, Jeong H, et al. Dynamics of viral load and anti-

618 SARS-CoV-2 antibodies in patients with positive RT-PCR results after recovery from COVID-19.

619 Korean J Intern Med. 2021;36(1):11-4. Epub 2020/09/26. doi: 10.3904/kjim.2020.325. PubMed

620 PMID: 32972123; PubMed Central PMCID: PMCPMC7820639.

621 71. Fernandes Valente Takeda C, Moura de Almeida M, Goncalves de Aguiar Gomes R, Cisne

622 Souza T, Alves de Lima Mota M, Pamplona de Goes Cavalcanti L, et al. Case Report: Recurrent

623 Clinical Symptoms of COVID-19 in Healthcare Professionals: A Series of Cases from Brazil. Am J

624 Trop Med Hyg. 2020;103(5):1993-6. Epub 2020/09/06. doi: 10.4269/ajtmh.20-0893. PubMed

625 PMID: 32888288; PubMed Central PMCID: PMCPMC7646791. 
medRxiv preprint doi: https://doi.org/10.1101/2021.07.22.21260972; this version posted July 25, 2021. The copyright holder for this preprint (which was not certified by peer review) is the author/funder, who has granted medRxiv a license to display the preprint in perpetuity.

All rights reserved. No reuse allowed without permission.

626 72. Tian $\mathrm{M}$, Long $\mathrm{Y}$, Hong $\mathrm{Y}$, Zhang $\mathrm{X}$, Zha $\mathrm{Y}$. The treatment and follow-up of 'recurrence'

627 with discharged COVID-19 patients: data from Guizhou, China. Environ Microbiol.

628

2020;22(8):3588-92. Epub 2020/07/08. doi: 10.1111/1462-2920.15156. PubMed PMID:

629

$32632947 ;$ PubMed Central PMCID: PMCPMC7361525.

630

73. To KK, Hung IF, Ip JD, Chu AW, Chan WM, Tam AR, et al. COVID-19 re-infection by a

631

phylogenetically distinct SARS-coronavirus-2 strain confirmed by whole genome sequencing.

632 Clin Infect Dis. 2020. Epub 2020/08/26. doi: 10.1093/cid/ciaa1275. PubMed PMID: 32840608;

633 PubMed Central PMCID: PMCPMC7499500.

634 74. Tomassini S, Kotecha D, Bird PW, Folwell A, Biju S, Tang JW. Setting the criteria for SARS-

635 CoV-2 reinfection - six possible cases. J Infect. 2021;82(2):282-327. Epub 2020/08/18. doi:

636 10.1016/j.jinf.2020.08.011. PubMed PMID: 32800801; PubMed Central PMCID:

637

PMCPMC7422822.

638 75. Torres DA, Ribeiro L, Riello A, Horovitz DDG, Pinto LFR, Croda J. Reinfection of COVID-19

639 after 3 months with a distinct and more aggressive clinical presentation: Case report. J Med

640 Virol. 2021;93(4):1857-9. Epub 2020/10/29. doi: 10.1002/jmv.26637. PubMed PMID: 33112002.

641 76. Van Elslande J, Vermeersch P, Vandervoort K, Wawina-Bokalanga T, Vanmechelen B,

642 Wollants E, et al. Symptomatic SARS-CoV-2 reinfection by a phylogenetically distinct strain. Clin

643 Infect Dis. 2020. Epub 2020/09/06. doi: 10.1093/cid/ciaa1330. PubMed PMID: 32887979;

644 PubMed Central PMCID: PMCPMC7499557.

645 77. Vetter P, Cordey S, Schibler M, Vieux L, Despres L, Laubscher F, et al. Clinical, virologic

646 and immunologic features of a mild case of SARS-CoV-2 reinfection. Clin Microbiol Infect. 
medRxiv preprint doi: https://doi.org/10.1101/2021.07.22.21260972; this version posted July 25, 2021. The copyright holder for this preprint (which was not certified by peer review) is the author/funder, who has granted medRxiv a license to display the preprint in perpetuity.

647 2021;国:1-. Epub 2021/02/23. doi: 10.1016/j.cmi.2021.02.010. PubMed PMID: 33618012;

648

649

650

651

652

653

654

655

656

657

658

659

660

661

662

663

664

665

666

PubMed Central PMCID: PMCPMC7896115.

78. West J, Everden S, Nikitas N. A case of COVID-19 reinfection in the UK. Clin Med (Lond).

2021;21(1):e52-e3. Epub 2020/12/12. doi: 10.7861/clinmed.2020-0912. PubMed PMID:

33303623; PubMed Central PMCID: PMCPMC7850175.

79. Wu J, Cheng J, Shi X, Liu J, Huang B, Zhao X, et al. Recurrence of SARS-CoV-2 nucleic acid positive test in patients with COVID-19: a report of two cases. BMC Pulm Med. 2020;20(1):308.

Epub 2020/11/24. doi: 10.1186/s12890-020-01348-8. PubMed PMID: 33225932; PubMed Central PMCID: PMCPMC7681189.

80. Yadav S, Wadhwa T, Thakkar D, Kapoor R, Rastogi N, Sarma S. Covid19 Reinfection in Two Children with Cancer. Authorea Preprints. 2020. doi: 10.22541/au.159986505.57940176.

81. Yadav SP, Thakkar D, Bhoyar RC, Jain A, Wadhwa T, Imran M, et al. Asymptomatic reactivation of SARS-CoV-2 in a child with neuroblastoma characterised by whole genome sequencing. IDCases. 2021;23:e01018. Epub 2020/12/09. doi: 10.1016/j.idcr.2020.e01018. PubMed PMID: 33288996; PubMed Central PMCID: PMCPMC7711173.

82. Ye G, Pan Z, Pan Y, Deng Q, Chen L, Li J, et al. Clinical characteristics of severe acute respiratory syndrome coronavirus 2 reactivation. J Infect. 2020;80(5):e14-e7. Epub 2020/03/17. doi: 10.1016/j.jinf.2020.03.001. PubMed PMID: 32171867; PubMed Central PMCID: PMCPMC7102560.

83. Yoo SY, Lee Y, Lee GH, Kim DH. Reactivation of SARS-CoV-2 after recovery. Pediatr Int. 2020;62(7):879-81. Epub 2020/05/19. doi: 10.1111/ped.14312. PubMed PMID: 32421910; PubMed Central PMCID: PMCPMC7276786. 
medRxiv preprint doi: https://doi.org/10.1101/2021.07.22.21260972; this version posted July 25, 2021. The copyright holder for this preprint (which was not certified by peer review) is the author/funder, who has granted medRxiv a license to display the preprint in perpetuity.

All rights reserved. No reuse allowed without permission.

669

670

671

672

673

674

675

676

677

678

679

680

681

682

683

684

685

686

687

688

689

690

84. Yuan J, Kou S, Liang Y, Zeng J, Pan Y, Liu L. Polymerase Chain Reaction Assays Reverted

to Positive in 25 Discharged Patients With COVID-19. Clin Infect Dis. 2020;71(16):2230-2. Epub

2020/04/09. doi: 10.1093/cid/ciaa398. PubMed PMID: 32266381; PubMed Central PMCID:

PMCPMC7184423.

85. Zayet S, Royer PY, Toko L, Pierron A, Gendrin V, Klopfenstein T. Recurrence of COVID-19

after recovery ? A case series in health care workers, France. Microbes Infect. 2021:104803.

Epub 2021/03/06. doi: 10.1016/j.micinf.2021.104803. PubMed PMID: 33667643; PubMed

Central PMCID: PMCPMC7923857.

86. Zhang B, Liu S, Dong Y, Zhang L, Zhong Q, Zou Y, et al. Positive rectal swabs in young patients recovered from coronavirus disease 2019 (COVID-19). J Infect. 2020;81(2):e49-e52.

Epub 2020/04/27. doi: 10.1016/j.jinf.2020.04.023. PubMed PMID: 32335176; PubMed Central PMCID: PMCPMC7177113.

87. Zhao W, Wang Y, Tang Y, Zhao W, Fan Y, Liu G, et al. Characteristics of Children With Reactivation of SARS-CoV-2 Infection After Hospital Discharge. Clin Pediatr (Phila). 2020;59(9-

10):929-32. Epub 2020/05/29. doi: 10.1177/0009922820928057. PubMed PMID: 32462940.

88. Zheng J, Zhou R, Chen F, Tang G, Wu K, Li F, et al. Incidence, clinical course and risk factor for recurrent PCR positivity in discharged COVID-19 patients in Guangzhou, China: A prospective cohort study. PLoS Negl Trop Dis. 2020;14(8):e0008648. Epub 2020/09/01. doi:

10.1371/journal.pntd.0008648. PubMed PMID: 32866168; PubMed Central PMCID:

PMCPMC7505432.

89. Zheng KI, Wang XB, Jin XH, Liu WY, Gao F, Chen YP, et al. A Case Series of Recurrent Viral RNA Positivity in Recovered COVID-19 Chinese Patients. J Gen Intern Med. 2020;35(7):2205-6. 
medRxiv preprint doi: https://doi.org/10.1101/2021.07.22.21260972; this version posted July 25, 2021. The copyright holder for this preprint (which was not certified by peer review) is the author/funder, who has granted medRxiv a license to display the preprint in perpetuity.

All rights reserved. No reuse allowed without permission.

691

692

693

694

695

696

697

698

699

700

701

702

703

704

705

706

707

708

709

710

711

712

Epub 2020/04/22. doi: 10.1007/s11606-020-05822-1. PubMed PMID: 32314129; PubMed

Central PMCID: PMCPMC7169645.

90. Zhu H, Fu L, Jin Y, Shao J, Zhang S, Zheng N, et al. Clinical features of COVID-19

convalescent patients with re-positive nucleic acid detection. J Clin Lab Anal.

2020;34(7):e23392. Epub 2020/06/09. doi: 10.1002/jcla.23392. PubMed PMID: 32506726;

PubMed Central PMCID: PMCPMC7300578.

91. Zucman N, Uhel F, Descamps D, Roux D, Ricard JD. Severe reinfection with South African

SARS-CoV-2 variant 501Y.V2: A case report. Clin Infect Dis. 2021. Epub 2021/02/11. doi:

10.1093/cid/ciab129. PubMed PMID: 33566076; PubMed Central PMCID: PMCPMC7929064.

92. Padda I, Khehra N, Jaferi U, Mosabbeh D, Atwal H, Musaji A, et al. Organ system effects

and reinfection of COVID-19: A systematic review. Journal of Research in Clinical Medicine.

2021;9(1):6-. doi: 10.34172/jrcm.2021.006.

93. SeyedAlinaghi S, Oliaei S, Kianzad S, Afsahi AM, MohsseniPour M, Barzegary A, et al.

Reinfection risk of novel coronavirus (COVID-19): A systematic review of current evidence.

World J Virol. 2020;9(5):79-90. Epub 2020/12/29. doi: 10.5501/wjv.v9.i5.79. PubMed PMID:

33363000; PubMed Central PMCID: PMCPMC7747024.

94. Irfan O, Muttalib F, Tang K, Jiang L, Lassi ZS, Bhutta Z. Clinical characteristics, treatment and outcomes of paediatric COVID-19: a systematic review and meta-analysis. Arch Dis Child. 2021. Epub 2021/02/18. doi: 10.1136/archdischild-2020-321385. PubMed PMID: 33593743.

95. Gidari A, Nofri M, Saccarelli L, Bastianelli S, Sabbatini S, Bozza S, et al. Is recurrence possible in coronavirus disease 2019 (COVID-19)? Case series and systematic review of literature. Eur J Clin Microbiol Infect Dis. 2021;40(1):1-12. Epub 2020/10/11. doi: 
medRxiv preprint doi: https://doi.org/10.1101/2021.07.22.21260972; this version posted July 25, 2021. The copyright holder for this preprint (which was not certified by peer review) is the author/funder, who has granted medRxiv a license to display the preprint in perpetuity.

All rights reserved. No reuse allowed without permission.

713

714

715

716

717

718

719

720

721

722

723

724

725

726

727

728

729

730

731

732

733

10.1007/s10096-020-04057-6. PubMed PMID: 33037944; PubMed Central PMCID:

PMCPMC7547550.

96. Vancsa S, Dembrovszky F, Farkas N, Szako L, Teutsch B, Bunduc S, et al. Repeated SARS-

CoV-2 Positivity: Analysis of 123 Cases. Viruses. 2021;13(3). Epub 2021/04/04. doi:

10.3390/v13030512. PubMed PMID: 33808867; PubMed Central PMCID: PMCPMC8003803.

97. Wang D, Hu B, Hu C, Zhu F, Liu X, Zhang J, et al. Clinical Characteristics of 138

Hospitalized Patients With 2019 Novel Coronavirus-Infected Pneumonia in Wuhan, China.

JAMA. 2020;323(11):1061-9. Epub 2020/02/08. doi: 10.1001/jama.2020.1585. PubMed PMID:

32031570; PubMed Central PMCID: PMCPMC7042881.

98. Badawi A, Ryoo SG. Prevalence of comorbidities in the Middle East respiratory

syndrome coronavirus (MERS-CoV): a systematic review and meta-analysis. Int J Infect Dis.

2016;49(Aug):129-33. Epub 2016/06/30. doi: 10.1016/j.ijid.2016.06.015. PubMed PMID:

27352628 ; PubMed Central PMCID: PMCPMC7110556.

99. Wang J, Kaperak C, Sato T, Sakuraba A. COVID-19 reinfection: A Rapid Systematic Review of Case Reports and Case Series. medRxiv. 2021:2021.03.22.21254081. doi:

10.1101/2021.03.22.21254081.

100. Choudhary MC, Crain CR, Qiu X, Hanage W, Li JZ. SARS-CoV-2 Sequence Characteristics of COVID-19 Persistence and Reinfection. Clin Infect Dis. 2021;(2021). Epub 2021/04/28. doi:

10.1093/cid/ciab380. PubMed PMID: 33906227.

101. Arkhipova-Jenkins I, Helfand M, Armstrong C, Gean E, Anderson J, Paynter RA, et al.

Antibody Response After SARS-CoV-2 Infection and Implications for Immunity : A Rapid Living 
medRxiv preprint doi: https://doi.org/10.1101/2021.07.22.21260972; this version posted July 25, 2021. The copyright holder for this preprint (which was not certified by peer review) is the author/funder, who has granted medRxiv a license to display the preprint in perpetuity.

All rights reserved. No reuse allowed without permission.

734 Review. Ann Intern Med. 2021. Epub 2021/03/16. doi: 10.7326/M20-7547. PubMed PMID:

33721517; PubMed Central PMCID: PMCPMC8025942.

102. Piri SM, Edalatfar M, Shool S, Jalalian MN, Tavakolpour S. A systematic review on the

737 recurrence of SARS-CoV-2 virus: frequency, risk factors, and possible explanations. Infect Dis

738 (Lond). 2021;53(5):315-24. Epub 2021/01/30. doi: 10.1080/23744235.2020.1871066. PubMed

PMID: 33508989; PubMed Central PMCID: PMCPMC7852280.

103. Azam M, Sulistiana R, Ratnawati M, Fibriana AI, Bahrudin U, Widyaningrum D, et al.

Recurrent SARS-CoV-2 RNA positivity after COVID-19: a systematic review and meta-analysis.

Sci Rep. 2020;10(1):20692. Epub 2020/11/28. doi: 10.1038/s41598-020-77739-y. PubMed

PMID: 33244060; PubMed Central PMCID: PMCPMC7691365.

104. Hoang T. Systematic review and meta-analysis of factors associated with re-positive viral

RNA after recovery from COVID-19. J Med Virol. 2021;93(4):2234-42. Epub 2020/11/03. doi:

10.1002/jmv.26648. PubMed PMID: 33135788.

747 105. NBS. Home - Regional - Quarterly by Province. 2019.

106. Gan N. Beyond India, a growing number of Asian countries are being ravaged by fresh

751 coronavirus waves. CNN. 2021 May 82021.

752 107. Kothari A, Pfuhl G, Schieferdecker D, Harris CT, Tidwell C, Fitzpatrick KM, et al. The

753 Barrier to Vaccination Is Not Vaccine Hesitancy: Patterns of COVID-19 Vaccine Acceptance over

754 the Course of the Pandemic in 23 Countries. medRxiv. 2021:2021.04.23.21253857. doi: 
medRxiv preprint doi: https://doi.org/10.1101/2021.07.22.21260972; this version posted July 25, 2021. The copyright holder for this preprint (which was not certified by peer review) is the author/funder, who has granted medRxiv a license to display the preprint in perpetuity.

All rights reserved. No reuse allowed without permission.

756 108. Haas EJ, Angulo FJ, McLaughlin JM, Anis E, Singer SR, Khan F, et al. Impact and

757 effectiveness of mRNA BNT162b2 vaccine against SARS-CoV-2 infections and COVID-19 cases,

758 hospitalisations, and deaths following a nationwide vaccination campaign in Israel: an

759 observational study using national surveillance data. The Lancet. doi: 10.1016/SO140-

$760 \quad 6736(21) 00947-8$.

\section{Supporting information}

762 S1 Table. Search Strategy for MEDLINE

763 S2 Table. Characteristics of included studies ( $\mathbf{N}=\mathbf{8 1})$

764 S3 Table. Quality assessment of case reports and case series ( $N=81)$

765 S1 Fig. Global map of distribution of the studies included $(\mathbf{N}=81)$ in the review

766 S1 Appendix. PRISMA checklist 
Records identified through database searching ( $n=1039$ )
Additional records identified through other sources $(n=10)$

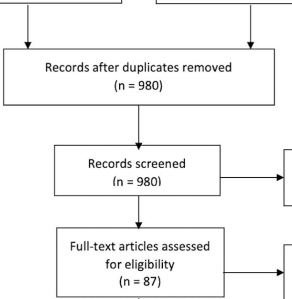

Records excluded ( $n=893$ )

Full-text articles excluded, with reasons $(n=6)$

Studies included in quantitative synthesis (meta-analysis)

$$
(\mathrm{n}=81)
$$

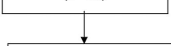

Studies included in qualitative synthesis

$$
\text { ( } n=81 \text { ) }
$$


Odds Ratio

Study or Subgroup Events Total Events Total Weight M.H, Random, $95 \% \mathrm{Cl}$ M.H, Random, $95 \% \mathrm{Cl}$

\begin{tabular}{|c|c|c|c|c|c|c|}
\hline Dyspnea & 54 & 577 & 99 & 577 & $12.6 \%$ & $0.50[0.35,0.71]$ \\
\hline Fatigue & 63 & 577 & 87 & 577 & $12.8 \%$ & $0.69[0.49,0.98]$ \\
\hline Myalgia & 80 & 577 & 88 & 577 & $13.2 \%$ & $0.89[0.64,1.24]$ \\
\hline Cough & 201 & 577 & 201 & 577 & $15.0 \%$ & $1.00[0,78,1,27]$ \\
\hline Headache & 56 & 577 & 56 & 577 & $11.3 \%$ & $1.00[0.68,1.48]$ \\
\hline Sore throat & 30 & 577 & 29 & 577 & $9.3 \%$ & $1.04[0.61,1,75]$ \\
\hline Fever & 239 & 577 & 210 & 577 & $15.1 \%$ & $1.24[0.97,1,57]$ \\
\hline Diarnhea & 45 & 577 & 30 & 577 & $10.1 \%$ & $1.54[0.96,2.49]$ \\
\hline Total $(95 \%$ Cl) & & 4616 & & 4616 & $100.0 \%$ & $0.93[0.74,1.17]$ \\
\hline Total events & 768 & & 800 & & & \\
\hline
\end{tabular}

Heterogeneity. Tau $^{2}=0.08, \mathrm{Ch}^{2}=25.16, \mathrm{df}=7(\mathrm{P}=0.0007) ; \mathrm{P}=72 \%$ Test for overall effect $Z=0.61(P=0.54)$

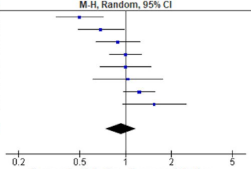

Favours first infection Favours reinfection. 
First infection Reinfection

Odds Ratio

Odds Ratio

Study or Subgroup

Events Total Events Total Weight M-H, Random, 95\% Cl

Random, $95 \% \mathrm{Cl}$

\begin{tabular}{lrrrrrr}
\hline Antibiotics & 83 & 577 & 76 & 577 & $18.2 \%$ & $1.11[0.79,1.55]$ \\
Antrviral therapy & 257 & 577 & 248 & 577 & $19.8 \%$ & $1.07[0.84,1.34]$ \\
ICU admission & 3 & 577 & 10 & 577 & $5.7 \%$ & $0.30[0.08,1.08]$ \\
Interferon-a & 62 & 577 & 44 & 577 & $17.0 \%$ & $1.46[0.97,2.19]$ \\
Low flow oxygen & 35 & 577 & 71 & 577 & $16.7 \%$ & $0.46[0.30,0.70]$ \\
Mechanical ventilation & 2 & 577 & 9 & 577 & $4.4 \%$ & $0.22[0.05,1.02]$ \\
Steroids & 96 & 577 & 70 & 577 & $18.3 \%$ & $1.45[1.04,2.02]$ \\
& & & & & & \\
Total (95\% Cl) & 538 & & 528 & &
\end{tabular}

Total events

$\mathrm{Chi}^{2}=28.52, \mathrm{df}=6(\mathrm{P}<0.0001) ;\left.\right|^{2}=79 \%$

Heterogeneity: $\mathrm{Tau}^{2}=0.16 ; \mathrm{Ch}^{2}=28.52$
Test for overall effect $Z=0.56(P=0.58)$

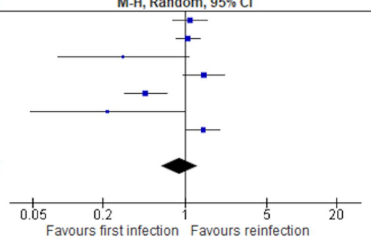

